\title{
CULTURE OVER STRUCTURE: THE HERITAGE OF LIFESTYLE RESEARCH IN THE 1970S IN HUNGARY AND POLAND
}

Piotr Filipkowski

Institute of Philosophy and Sociology, Polish Academy of Sciences, Warsaw

Judit Gárdos

Centre for Social Sciences, Hungarian Academy of Sciences, Budapest Éva Kovács

Centre for Social Sciences, Hungarian Academy of Sciences, Budapest

Vera Szabari

Eötvös Loránd University, Budapest

"In the effort to construct a socialist society the problems of lifestyle present themselves more and more urgently, both on the ideological and the empirical level. Is there an authentic form of socialist lifestyle, and can we consciously form or influence this model during the construction of the economy and society?” - with these words the sociologist János Szántó summarised the results of a giant sociological research project on "socialist lifestyle" in Hungary (1978: 5). ${ }^{1}$ In 1975, an international sociological conference was held in Budapest. Sociologists from Czechoslovakia, Hungary, Poland, and the Soviet Union presented their research findings on the same topic. "Lifestyle" is the word that was used in the original documents and publications for the core topic of the research. At this conference, the Eastern European social scientists, including Szántó, tried for the first time to elaborate "the characteristics of the socialist lifestyle" in a theoretical (and ideological) context. Szántó (1978: 145) writes that "socialist lifestyle - if we understand the term correctly - means the mode of life of people living in a society of developed socialism." Primarily, the participants of the conference discussed the conceptual framework of life-

\footnotetext{
${ }^{1}$ All translations of cited fragments are our own.
} 
style research, but they also thematised methodological questions such as the quantification of social phenomena, modelling possibilities, and using statistical data for sociological analyses. The researchers did not use a single, canonised definition of lifestyle, instead we find different and parallel concepts in the most important publications on the topic at the time. For example, one of the main figures of lifestyle research in Hungary, Ágnes Losonczi, states that they were interested in how "people plan, organise, live, and think their lives. We consider basic facts like the material-social conditions, what role everyday survival plays in these conditions, how these people relate to the work that sustains society and fills a major part of their lives, what they think are the most important goals and experiences of life, and what they regard as important" (Losonczi 1978: 44-45). István Kemény, one of the most influential sociologists of that era, wrote in 1973 that "a lifestyle connects those living it and disconnects them from those living other lifestyles" (1992: 135). He argues that lifestyle forms every part of life and personality, and is also continuously changing and linked to the social context (Kemény 1992: 136). Roughly at the same time, Andrzej Siciński, ${ }^{2}$ a prominent Polish sociologist, started organising a multidisciplinary research team to conceptualise different Polish lifestyles and later to observe them empirically. One of the key differentiation criteria was (or was supposed to be) belonging to either the group of the intelligentsia or of the workers, while differences between rural and urban lifestyles played a significant role as well (Siciński 1978a: 135).

Three years after the above-mentioned conference, seven Hungar$\operatorname{ian}^{3}$ and one or two further authors from each guest country ${ }^{4}$ published their articles in a monograph entitled Lifestyle Research in the Socialist Countries (Szántó 1978). On reading these articles, a permanent desire for dialogue with mainstream Western sociology can be identified. The writers quoted

\footnotetext{
${ }^{2}$ Andrzej Siciński (1924-2006) was one of the most versatile and active post-war academic Polish sociologists. He graduated from Warsaw University in 1952; in 1961 he defended his Ph.D. there. Afterwards, he was one of the animators of Polish intellectual life, gathering around himself people with different academic backgrounds, worldviews, and political preferences. He was the leader of several interdisciplinary working teams at the Polish Academy of Sciences, conducting theoretical and empirical research projects on, among other subjects, contemporary culture; visions of the future (a famous international research project with the Norwegian sociologist John Galtung); Polish lifestyles in the 1970s (described in this paper); emerging civic society (the latter research tradition is still being continued by his followers). He was also the co-founder of OBOP in 1958 - Poland's first public opinion research institute - and later a path-breaking qualitative methodologist; he was also an adviser to Solidarity in 1980 and Minister of Culture in the early 1990s.

${ }^{3}$ K. Kulcsár, Á. Losonczi, M. Szántó, E. Hankiss, R. Manchin, R. Andorka, and L. Cseh-Szombathy.

${ }^{4}$ A. Siciński, N.S. Mansurov, V.Z. Rogovin, M. Illner, and B. Filipcová.
} 
- aside from Marx and Engels - from Parsons, Malinowski, and Weber, to Hall, Heller, and Campbell. Nevertheless, there are a limited number of similarities with Western sociology to be observed among the concepts and methods of the national studies. The comparative analyses with Western societies remained unfinished and artificial. It seems that this first attempt to canonise Eastern European (socialist) knowledge on a transnational level failed. Probably the failure did not originate from socialist-type sociological thought but from the research question itself; as has been stated more than once, the question of everyday life in the social sciences is vast (Highmore 2002: 1) and can include practically any theme, such as language, rules, positions, or performances (Kalekin-Fishman 2013: 715).

Research on everyday life seems to have played a double role in the socialist society of the 1970s. On the one hand, it is seen now by researchers, a posteriori, as a critical tool for unmasking the poverty and deprivation that was officially denied at the time but was still very much present in socialist society. On the other, it was seen in that period as a tool for helping ameliorate the system and, in parallel, to legitimise the "socialist way of life." This dualism is also observable in the status of the Hungarian and Polish research groups. Both were funded or ideologically influenced by the State and the Party, but at the same time, they were sheltered areas, where intellectuals and researchers belonging to the opposition could work rather freely. Both the influence of ideological questions and the relative independence of the scientific field (compared to the previous period) are observable in each of the cases.

Two research collections from the 1970s on the everyday life of Hungarian and Polish industrial employees have recently been found in the unorganised archives of the Hungarian and the Polish Academies of Sciences. These documents provide considerable empirical material to support our argument.

\section{/// 1. The Concept of Lifestyle in the Hungarian and Polish Sociological Traditions}

\subsection{Hungary - from the Hungarian Peasant to the Time-Budget Analysis}

Lifestyle research has a long and unique tradition in Hungary. At the fin de siècle, the sociologist Róber Braun, inspired by William I. Thomas, con- 
ducted a survey on the everyday life of the Hungarian peasants (Braun 1913). In the interwar period, some of the "populist writers" (Erdei 1933; Illyés 1936; Kovács 1937; Szabó 1936, 1938; Veres 1936) produced descriptive works ("sociographies") and political pamphlets based on the daily life of the peasants. These authors focused on the impoverished living conditions in an impressionistic and politically motivated way. Their political scope reached from the far left to the far right, but their highly critical accounts were made from a strong moral position. The writers' influence was due, on the one hand, to their double status on the boundary of politics, sciences and literature, on the other hand, to the lack of an autonomous, scientific, sociology (Bourdieu 1999).

Sociology in Eastern Europe came to a halt after the Second World War and with the communist parties' takeover of the region. Classical sociological research topics reappeared at the beginning of the 1960s, when sociology re-emerged as a scientific and institutionalised discipline in Hungary. Following the Soviet model, a sociological research group was created at the Institute of Philosophy, at the Hungarian Academy of Sciences (HAS), in 1960. The consolidation of János Kádár's ${ }^{5}$ regime played an important role in the reorganisation of sociological research, even if the period of détente after the defeat of the 1956 revolution was not without troubles. According to the dogmatic Marxist viewpoint, there was no need for independent sociology alongside historical materialism. Sociologists who wished to restart the discipline had to depart from the principles of historical materialism and Marxist sociology to legitimise a field of sociology independent of Marxist social science, to produce a methodology, and to familiarise themselves with and become accepted by non-Marxist schools of sociology. In 1963, András Hegedüs became head of the independent Research Group. Hegedüs had been prime minister in 1956 after the defeat of the revolution, but had abandoned politics and turned to social science in the early 1960s, after a forced emigration in Moscow. Some members of the Group were influenced by the ideas of Lukács's Budapest School (Heller 1970) and they in part defined sociology as a kind of socialist criticism. Thus, in the 1960s sociology was politicised; it did not have a solid institu-

\footnotetext{
${ }^{5}$ János Kádár (1912-1989) was a Hungarian communist politician; he was the prime minister of the Revolutionary Workers'-Peasants' Government established by the Soviets in 1956, which was tasked with halting the national uprising of the Hungarians. From 1957 to 1988 he headed the Hungarian Socialist Workers' Party. He directed repressions against the participants in the Hungarian revolution. Subsequently, he conducted a series of economic and political reforms, which ensured a fairly high standard of living for Hungarians. The system he created is called "Goulash Communism.”
} 
tional framework and professional representatives. Members of Hegedüs's group arrived from different disciplines without proper scientific questions and methodology. Their common aim was to show the distance between ideology and society; the lifestyle topic seemed ideal for them. In addition, it was a perfect research programme for critically minded scholars who were interested in the so-called Western sociological empirical methods rather than in Marxist theories of society. However, the programme was not completely independent of Hungarian research. Sándor Szalai, who worked at the United Nations Institute for Training and Research (UNITAR) in New York from 1966, developed a new method of lifestyle research. The method he used most prominently, the time-measurement coding scheme for analysing the structure of everyday life (Szalai 1972), became one of the Hungarian methods to have most influence in international sociology of the twentieth century.

Aside from Szalai's formalised, mathematically elaborated method, most sociological works were more political and ideological manifestations than significant scientific studies, although they triggered discussions in the socialist public sphere (Heller et al. 1992). This kind of criticism, which developed under the influence of the political system, both criticised and, unintentionally, also advanced the legitimacy of the political system in the 1960s. The obvious questions regarding the role of state socialism in shaping people's daily lives remained taboo.

In the 1970s, as a consequence of stronger political pressure, Hungarian sociology escaped into professionalisation. Hungarian sociologists (Andorka 1970; Hankiss 1977; Losonczi 1977; Szalai 1972; Szelényi 1973) developed more complex disciplinary and methodological approaches, which led to sociology becoming more autonomous on the one hand, while receding from the public conversation on the other. In the 1970s, departments of sociology were established at universities, promoting the professionalisation of the discipline.

\subsection{Poland - from the Polish Peasant to a Humanist Sociology}

In the 1970s, the two countries' almost parallel research interests in everyday life seemed to be completely disconnected; in the rich Polish literature on these research endeavours, no reference can be found to the work being done in Hungary. In fact, all that we have learnt stems from our analyses of the literature and the empirical data that were produced in both countries - and put aside for many years. 
The intellectual roots of the largest Polish sociological study of lifestyles, which was conducted by scholars working at the Institute of Philosophy and Sociology of the Polish Academy of Sciences are twofold. One is the strong and influential tradition of humanistic sociology in Poland. We write "humanistic" and not (solely) "qualitative" or "interpretive" to stress the sizable impact of the theoretical concepts and methodological recommendations of Florian Znaniecki, the founding father of Polish sociology.

Znaniecki has a well-established position in the history of sociology, mostly thanks to his cooperation with William I. Thomas and their joint, monumental work The Polish Peasant in Europe and America (1918-1920). But the most often quoted passages from Znaniecki's work do not come from his substantive analysis of the rich autobiographical material (letters, diaries, autobiographies) he collected from Polish peasants or, later, from workers, but from the theoretical and methodological considerations that led him to develop (Znaniecki 1922, 1927) what he called the "humanistic coefficient" (wspótczynnik bumanistyczny). What is sometimes called "the Polish method" in sociology (Bertaux 1981), that is, collecting vast autobiographical material by organising open competitions for written memoirs (pamietniki) in order to develop, inductively, sociological generalisations which might be interpreted as direct adaptations of the above-mentioned "humanistic coefficient" (Konecki et al. 2005). Znaniecki had organised such a competition among workers for the first time in 1921. This research method continued on a large scale until the 1970s.

The extensive research on lifestyles started by the Institute of Philosophy and Sociology at the PAS is not simply a continuation of this qualitatively, biographically, and individualistically oriented sociological tradition. The methods were different, although the stated research goal was similar: to grasp the individual in his or her social and/or cultural "entirety."

It was an attempt to implement these new, qualitatively oriented perspectives into sociological theorising and empirical research practice - to make them visible to a sociological mainstream dominated by positivist theoretical approaches and focused on researching social structures. ${ }^{6}$

\footnotetext{
${ }^{6}$ In this context the name of Stefan Nowak (1924-1989), another prominent Polish sociologist of the same post-war generation, should be mentioned. At the time when Siciński was conceptualising and realising a methodologically novel, qualitative research programme on Polish "lifestyles," Nowak was nuancing and sophisticating a quantitative, questionnaire-based analysis of Polish society, and particularly its "system of values." See his famous paper "System wartości społeczeństwa polskiego," (Nowak 1979), which is still widely discussed and used as a reference (in English, "Value Systems of Polish Society," (1980)).
} 
Looking at social reality from a lifestyle perspective meant, therefore, giving priority to culture over structure (or seeing both as equally important).

What might seem paradoxical today, especially from an outsiders' perspective, is that this was being done by one of the key Polish sociological institutions, financed with public money and approved by the ruling communist party, as in Hungary. Still, the PAS's Institute of Philosophy and Sociology, which was established on the wave of the political thaw of 1956 and gave shelter to many ideologically and politically "insubordinate" scholars, was probably the most liberal of the institutions where such a project could have been initiated. Siciński himself managed to balance perfectly between the party's acceptance if not outright support (some of his Institute colleagues were active party members and had political functions in the party apparatus), and at the same time surrounding himself with young, critical scholars, artists, and activists, who openly opposed the cultural and political mainstreams. All members of his team, no matter how different and opposing their worldviews, recalled Siciński very positively.

\section{/// 2. Lifestyle Research in the 1970s in Hungary and Poland}

\subsection{The Hungarian Sample}

Lifestyle was the topic of the first large-scale, complex empirical studies among different social groups after the Second World War in Hungary. How can the outstanding popularity of this research concept be explained? One way is to point to the importance of everyday life in international sociological research trends as a consequence of Parsons' theoretical hegemony (Parsons 1937). Another plausible answer resides in the idea of a "peaceful coexistence or competition" between the socialist and capitalist worlds, as announced by Richard Nixon. According to this idea, socialist governments also wanted to justify the success of their systems through the application of scientific data. One of the benchmarks was the well-being of people in the socialist system. In addition, due to the lack of real political elections, this particular scientific method was almost the only possibility for the political authorities to examine the habits and attitudes of the citizens and gather information on how they spent their time. In parallel to this development, the Kádár-regime used increased living standards to legitimise the socialist system (so-called "Goulash Socialism”). 
A couple of years ago, a dozen boxes of transcribed interviews and other research materials were found in the Institute of Sociology. The boxes turned out to contain the results of a research project on workers' lifestyle conducted in the mid-1970s in Budapest. The Voices of the 20th Century Archive and Research Group organised and catalogued the documents. ${ }^{7}$ The collection now contains approximately 600 documents on 195 interviewees. ${ }^{8}$ The data was collected in ten factories in Budapest. Due to the fragmentary nature of the collection, we cannot analyse it as if it were complete. But for a socio-historical, theoretical, or methodological analysis, this collection is very valuable.

In the collection, we find mainly primary data (we call it a file) on each interviewee, plus some draft analyses. A complete file of an interviewee includes four different texts:

a) An often very long, structured biographical interview with the focus on everyday life and cultural consumption. The research project collected detailed information on the biographical background, parents, family life, relationships, contacts, and social milieus of the interviewees. In the interviews, they talk about their childhood activities, school experiences, teachers, and cultural consumption (books, press, television). The interviewers asked numerous very general questions, for instance, about "things you dislike," "bad experiences in your life," and "things that make sense to you." Another focus of the interview was active participation in "higher culture" - obviously the only form of culture that was considered valuable by the researchers. It is clear by reading the texts based on this material that listening to beat music, spending time with friends, or recreations or hobbies such as gardening or handcrafts were not seen as important cultural activities. On the contrary, the aim of improving one's education in one's spare time was considered to be positive, and we see that high culture was favoured and thought to be the means of socialist culturalisation. In socialist theory, higher culture (Kultur in German) meant art films, classical music, and serious works of literature and was understand to be an

\footnotetext{
7 Project website in English: http://20szazadhangja.tk.mta.hu/en

8 The collection originally must have been much larger, since - as we know from the sources - approximately 1,200 people were interviewed and answered a questionnaire. The collection is fragmented; there are complete files missing, and in approximately $50 \%$ of the available files, one or more documents are missing. It is almost certain that all four types of documents were not made for every single file, since not all 1,200 people in the questionnaire-sample were interviewed.
} 
important factor for the emancipation of members of the working class.

b) A summary of the interview in regard to the interviewee's living conditions, parents, childhood, school, choice of profession, degree of culturalisation (the consumption and production of high culture), aims, and desires. We also find annotations of the interviewers about what is missing in the interview and evaluations of the life trajectory of the interviewees (for example, "a bad childhood," "lack of cultural background," "the personality of this person and his cultural needs have not been fully shaped yet," etc.).

c) An individual questionnaire with detailed questions about the interviewee's school, family, income, father's occupation, legal status of the interviewee's dwelling, questions about the furnishing of the dwelling, land ownership, group activities, and family life. We find detailed information for a time-budget analysis of cultural consumption at home on an average weekday and on weekends. Interestingly enough, no information was gathered on the shadow economy or alternative forms of production (e.g., DIY projects, or kaláka, a self-help means of build living space by organising friends and family). There are many questions on participation in culture and on the topic of the cultural goods consumed (press, radio, TV programmes, cinema, theatre, books, museums, and exhibitions). Changes of lifestyle and the social mobility of the interviewees were other recurrent topics.

d) A narrative comparison of the interview and the questionnaire by the interviewer, mentioning discrepancies in the answers between the interview and the questionnaire about how much and what cultural goods were consumed.

The research was conducted at the Institute of Culture, which existed from the 1970s until the 1990s in connection with the Centre for Sociology of the HAS. The Institute became a home for established social scientists, and members of the democratic opposition also participated as interviewers in the projects. Therefore, the group was politically mixed, and, as in Poland, was considered to be a sheltered environment by some researchers. The large amount of research focusing on lifestyle and everyday life was heavily funded by the Party, but the participants were not necessarily loyal in regard to Party directives. The research topic had to be interesting for the Party; nevertheless, one sees hardly any political topics, questions, or comments in the concrete raw material of the research project. In the theo- 
retical writings of the researchers, the aim of achieving a socialist society was in the foreground. However, for them, socialist society meant the inclusion of higher cultural activities that were common among the sociologists themselves (listening to Mozart and Bartók, or reading Shakespeare, for example). The cultural "nivelation" of the working class unintentionally thus meant inclusion in bourgeois cultural activities. A very important theme was enabling workers to have free time to spend as they wanted (but preferably "in a culturalised way").

Therefore, everyday life in this study was understood as a holistic term covering everything that was relevant for how the members of the sample spent their time (Szántó 1978). A very important normative goal of the researchers was to show whether people's workload enabled them to participate in other activities. These activities were seen in a very normative sense, with the aim being participation in high culture and activities contributing to a socialist society. Still, this focus took into account activities other than those of the workplace and the household. In the mid-1970s, it could have been used to make gender- or class-based claims about whether having a personal life outside of work and the fulfilment of personal desires was possible or not.

In a sense, lifestyle research was pioneering in Eastern European gender studies and the sociology of material culture and of the family. We would like to mention just a few examples: Aliz Mátyus's book (1980) about young women from the countryside living and working in Budapest, Judit H. Sas's (1981) book on "female women and male men," Ágnes Losonczi’s publication (1977) on "lifestyle in time, in objects, and values," or Mária Sági's study (n.d.) on "culture and individuum" around the same year. Losonczi also invented a triangular model to show the dynamics between social conditions (the conditional sphere), social actions (the kinetic sphere), and needs and motifs (Losonczi 1977). She also stressed that history is always embodied in the lifestyles of social classes and groups; thus, lifestyle is a dynamic category in the social sciences. Why are certain elements of a lifestyle resistant to social conditions and structural changes? How can historical changes explain the transformations in human needs and desires?

The above examples show that although in most cases there was a strong normative and critical perspective on lifestyle research, this research focused on very diverse issues and problems. The concept of lifestyle was suitable to link these fields. 


\subsection{The Polish Sample}

It has already been mentioned that Polish "lifestyle" research of the 1970s can be seen as an example, or even a manifestation, of an anti-positivistic turn in sociology. Let us look a bit closer at how it was conceptualised and realised in research practice. Such a closer look is possible today thanks to raw empirical data collected during the project and miraculously surviving all institutional and political changes. In the last few years the documents have been archived and made accessible for "re-visiting." This unique collection of research data became a cornerstone of a newly established Qualitative Data Archive at the Institute of Philosophy and Sociology at PAS - the same that conducted "lifestyle" research almost four decades ago."

But before coming to the collected data it is worth stressing the exceptionally rich body of literature that was written and published under its roof. As we have mentioned before, the vast majority of these publications do not confront collected empirical material at all; nevertheless, in many texts you can find assurances that fieldwork data is the core of the entire endeavour. This lack of analysis of the actual data collected is similar to the Hungarian lifestyle studies, where analysis of the collected material is also scarce.

Among the key publications that appeared in book form, two volumes were devoted to theoretical considerations on the category of lifestyle, with extensive references to contemporary, mostly Western, sociological theories on that very concept and its relatives: "way-of-life," "life-world," or the only seemingly simpler concept of the "everyday" (Siciński 1976, 1978b).

Another collection of publications connected to the lifestyle project focuses on methodology, or rather methods, as it presents research tools in a very detailed way (Siciński 1980; Siciński \& Wyka 1988). It is not easy to find any other (qualitative) research project in Polish sociology where this kind of documentation was so extensive and so transparent to the wider public. ${ }^{10}$ Still, what was thought to be the greatest value of the project namely, its empirical richness and density - is somehow missing at the end and hard to find in the texts presenting the project "findings." Why?

Some blame history (or History) for the delayed and insufficient analysis of the empirical data collected within the "lifestyle" project (Siciński

\footnotetext{
${ }^{9}$ Project website: http://adj.ifispan.pl/o_archiwum.

${ }_{10}$ The exception might be the research project on the Solidarity movement and moment, which had a large impact on the discipline and which legitimised qualitative approaches in Polish sociology to a far greater degree than the long-absent "lifestyle" research of Andrzej Siciński and his team. See Krzemiński et al. 2005 [1983]; Marody et al. 2004 [1981].
} 
1988). The fieldwork was conducted mainly in 1979 and finished at the beginning of 1980 - that is, at the very final, crisis stage of the Gierek decade, ${ }^{11}$ the year when the Solidarity strikes were ended by the introduction of martial law. These historical events had a direct impact on the research team. Siciński himself was a Solidarity advisor, and many of his project colleagues were involved in this social movement: some were even interned when martial law was instituted. Undoubtedly Siciński himself and other members of the research team had much more urgent things to do at the beginning of the 1980s than to interpret the data on lifestyles they had collected earlier, especially since the empirical material documented an "earlier" time - even if only a couple of months earlier - which no longer seemed relevant during the Solidarity breakthrough. The stress that had been placed on the stability and inertia of the lifestyles that had been researched and the lack of discovery of any signals of the approaching changes was retrospectively interpreted as a weakness of the whole research endeavour (Gawin 1999; Siciński 1985).

The core of the book summarising the empirical data (Siciński 1988) is a typology of these lifestyles illustrated by excerpts from empirical data. It seems as if the researchers constructed an intellectual framework that enabled them to present their empirical findings in a very clear, elegant, controlled way, at the cost of a radical reductionism and huge selectivity in coping with the collected data. This brings us to another explanation as to why it was so difficult to analyse the material for so many years: not only were there external historical reasons, but internal ones as well - the collected data was so extensive and rich that producing any non-superficial narrative to summarise and generalise it all was hardly possible. The typology of lifestyles can be seen today - when we have access to the raw data - as an attempt to get out of the trap.

This typology is constructed on one basic philosophical principle. Namely, that each person in society has some - larger or smaller - spectrum of free choice, which is used, or fulfilled, in very different ways. At one end of the spectrum is the avoidance of choice, at the other is orient-

11 Edward Gierek (1913-2001) was First Secretary of the Polish United Workers' Party (PZPR) in the years 1970-1980. This decade of his rule, which started with euphoric promises and widely shared optimism about modernisation, economic improvement, and - maybe most importantly in this context - the rise of individual consumption, finished with huge crises in 1980 . These were the direct cause of the social protest that led to Solidarity. Thus the abandonment of the lifestyle research data for several years might have had something to do with a feeling - which today is hard to prove empirically, of course - that research findings from before "the revolution," that did not foresee it, were somehow irrelevant or inadequate. After a longer time had passed, they seemed much more valuable, though. 
ing one's life toward constant change. In between, we have persons whose choices are repeated and form visible, stable patterns - or are changing but are still driven by clearly defined long-term biographical goals. Such a theoretical frame made it possible - quite astonishingly from today's perspective - to picture Polish workers and intellectuals as agents, as valuedriven choosers who actively shaped their own and their families' lives (and lifestyles). The collected empirical data easily fulfilled this deductive model. It was used to exemplify a concrete life orientation driven by one value or another (for example, family life, a career, independence, material goods, self-development, etc.). Was Polish society of the late 1970s really so "optional" and non-determining? Or were Siciński and his colleagues so politically naive that they adapted the successful propaganda language to interpret their research findings? Or were they rather deeply inspired and influenced by a subjective, humanistic thinking rooted in Znaniecki on the one hand, and the "schismatic" sociologies of the time on the other, leading them to look for strong human subjects and agents opposing the determining social (and socialist) reality? A positive answer to the last of these questions seems the most accurate. The translated title of the jubilee book for Sicińśki, written by his collaborators two decades after the lifestyle fieldwork, seems to confirm this: Homo eligens. Spoleczeństwo swiadomego wyboru [Homo Eligens: The Choice-Aware Society] (Gawin 1999).

Upon a closer inspection of the research design and practice visible in the collected material we can make the following observations. The Polish lifestyle research was conceptualised and conducted as research on families. Roughly eighty families - mainly workers, and some members of the intelligentsia - who were working in the same factories, were visited in their homes in four provincial cities: Gdańsk, Bydgoszcz, Lubin, and Dobre Miasto. The choice was dictated by historical reasons and the cities' different socio-economic development after the war. The first three were (heavy) industrial cities; the latter was a very small satellite town. The research in the Hungarian case was quite similar: most of the people interviewed were workers, or specialists with university degrees working in industry.

We are presenting the Polish "lifestyle" research as sociological, but Siciński and his team put considerable effort into collecting solid, dense, ethnographical material, which was intended from the beginning for sociological generalisations.

The general idea of observing a family's lifestyle - understood holistically - was written into a set of research steps, each having its special genre and narrative style. Therefore, each fully completed family folder consists 
of the following documents: a basic data sheet with personal information, a family questionnaire, biographical interviews (a transcript and/or audio file) with family members (usually with the family "head"), family pictures taken by the researcher or copied (photographed) from family albums, pictures of the household interiors, and the "appendix" and "researcher's diary," which were most often richest in content. This enigmatic appendix contained a detailed, precisely structured description of the "everyday" and "everything" of the families. The diary contained descriptions of family "behaviour" during the research process. Both these latter files were also full of researchers' opinions and self-expressions. Altogether we have, on average, around one hundred pages, and sometimes two hundred or more, of dense manuscript for each family.

On looking into these files we immediately see the richness, denseness, and heaviness of the collected material. The typology of "lifestyles" based on the free-choice principle (from almost fully determined people to almost free choosers of a life strategy) seems now a clever rhetorical tool to help depart from the complexity and weight of the data and return to the more secure ground of theoretical speculation. Life "as a whole," "as such," in its entire "style" happens not to be transferable to a set of sociological categories.

\section{/// 3. Similarities and Differences}

As we have seen, the Polish research was less politicised than the Hungarian. Polish sociologists and anthropologists - with an ethnographic focus - used the research as a good occasion to raise fundamental questions about "the nature" of sociological endeavour, turning the project into an internal, hermetic, theoretical and methodological dispute. Hungarian scholars, on the contrary, acted as objective observers providing a neutral description of society - one which would be understandable to the wider public.

However, there are more similarities than differences between the two approaches. Both research programmes were based on a holistic approach to understanding lifestyles. The Hungarian and Polish scholars wanted to describe the totality of social life, to understand and explain the complexity of socialist society. As old-fashioned scholars, they insisted on the category of "culture." They acted as missionaries of higher Kultur (either consciously and purposely in fulfilment of a political agenda, or unconsciously - showing their social and cultural distance to people they met "in the field"). But what does the consumption of high culture indicate? Our hypothesis is that 
in the light of the normativity observable in the scholarly discourse, high culture stands for the advanced (modern) society that was the aim of the socialist system at the time, where socialism's superiority over capitalism had to be measured and proved.

The areas of lifestyle research were hardly separable in the 1960s and 1970s, thus it was a suitable field for sociology, which had not yet been professionalised. The aim of the Hungarian and the Polish researchers was to map the whole life of a person and/or family; the researchers had a fundamentally holistic interest in the people they were studying. Both as regards quantity and quality the collected material is vast in comparison to sociological studies conducted in recent years. This presumably had to do with the fact that the research had a strong ideological background and thus heavy funding from the Party itself.

Compared to the particular research interests and very focused research questions of today, the aim of these researchers of forty years ago was to map the totality of the social life of the people and families under study. At least in Eastern Europe, this broad interest, in our view, is due to the critical outlook that scholarship adopted - and had to adopt - at that time.

We can risk the hypothesis that the most difficult methodological problem for the sociologists was the inclusion of the biographical interviews in their research analysis. Based on the later Hungarian publications, one can see that the researchers either returned to sociographical/anthropological descriptions, or they used the interview only to shape the questionnaire, or they later left out the interviews altogether and returned to a solely statistical analysis. But even the Polish lifestyle researchers, who were deeply rooted in a biographical tradition with its "humanistic coefficient," could not really take advantage of the interviews they had conducted to integrate "subjectivity" into their strict typologies. Ethnographic description and questionnaires go well with each other - the biographical narrative, however, fits neither one.

The great amount of theoretical and methodological literature produced within Polish lifestyle research, together with the extensive ethnographic data collected in the field (which is now archived and accessible) invite different kinds of re-visits of this material. The first confrontations show how difficult it was (and maybe still is, despite all the interdisciplinary thinking) to combine theoretical speculations on "culture," politically driven thinking on "society" from a macro-perspective, and ethnographic concentration on the singularity of individual (family) life, with what is 
perhaps the most difficult to integrate: an attempt to grasp individuals' sense of life through biographical interviewing. The final combination of these diverse and, on many points, opposite paths of thinking and of doing a kind of social research that was intended to provide a near-complete picture of the "lifestyles," "everyday," or "culture" of a particular social group at a particular time does not present a coherent picture. Instead, it offers a set of loosely connected puzzles. While examining them, we can learn much about how sociological knowledge was produced, and still more about the lives of people (but not necessarily their lifestyles) at that particular moment in time (Straczuk 2015).

\section{/// 4. Conclusion: The Socio-Historical Relevance of the Research from Today's Perspective}

The study of the socialist lifestyle was popular due to its Janus-faced character. It may have contributed to bringing criticism against the socialist system into the public sphere, and, along with the idea of "fridge" or "goulash socialism" (Dombos \& Pellandini-Simányi 2012: 325-350; Kornai 1996; Kovács 2009) may have helped to "freeze" the imaginary socialist ideology itself. In the context of contemporary mainstream social sciences, in this era of professionalism, the aim of trying to understand and grasp a human life in its totality might seem naive. Specific, limited scientific questions tend to dominate current sociology, especially in Eastern Europe. Limited funding possibilities do not allow for such large and diverse research projects.

In the writing of social history, everyday life (or Alltagsgeschichte) - which is sometimes considered to be a synonym of mentality (Mentalitätsgeschichte) or lifestyle - has become a tool for describing the social and cultural life of ordinary people. The concept of everyday life focused attention on the history of social classes and groups, and encouraged a departure from the long historiographical tradition of ignoring the society behind great events and famous personalities.

In the last decades, there has been a renaissance of the study of everyday life in socialism. In this research, the concept of everyday life is similar to that in the sociological research projects of the 1970s and 1980s. On the one hand, both have a focus on the macro-level, on the other, they are both searching for the "average" people of a certain class or social stratum. Thus, both have to confront the phenomenon of Eigen-Sinn (Lüdtke 1995) - or as Highmore put it, the question of whether everyday life is the 
realm of conformity or of resistance (Highmore 2002). In both our cases, there was, from the researchers' side, a demand for conformity regarding cultural consumption and the use of high culture in everyday life, but real consumption did not fulfil this demand. It was ideologically not supported to have other cultural patterns of consumption, so our knowledge of the complexity of real cultural habits remains fragmented. These "old" sociological sources provide an unusually large amount of material for writing social history. But the complexity that remains in the shadow has to be uncovered with other research material not included in this collection. Last but not least, it might be hazardous that current socio-historical studies of socialism often use the results of former sociological approaches as scientific facts without any critical reconstruction of the nature of the information produced, the researchers' presuppositions and foundations, and the set of overarching socialist doctrines or beliefs in these approaches (Majtényi 2014).

Among the core questions of the research in the 1970s in Hungary were how well a person could satisfy their higher (cultural) needs, and whether their workload enabled them to have fulfilled private and community lives. The focus at the time was thus on evaluating the existing communist society in Hungary. In Polish lifestyle research, even though it was partly driven by different motivations, a very similar, normative (even pastoral) thinking was present in the background: a person's life should be "fulfilled" - it should make sense. The similar research question of whether modern, now capitalist, society in Hungary (or elsewhere as a matter of fact) is contributing to the fulfilment of personal goals and a richer life is rarely asked. A contemporary social science that asked the question would be a fundamentally critical one. Should we take this old collection as an example?

In the Hungarian research of the 1970s, a clear normative trace was obvious. Participation in high culture and active, creative personal cultural activities were regarded as the non plus ultra of human activity. This clearly cannot be the starting point of a state-of-the art social science inquiry. However, the narrative interviews in this collection give us a rare insight into the everyday life of these people. Similar contemporary research projects on personal happiness appear in the social sciences as often descriptive, survey-based, small-scale research questions. We cannot really grasp the personalities, the life stories, behind the people in such samples. And such projects rarely tell us anything about the system and the life-world of people in a (post)modern society (Habermas 1981). 
However critically we think and write today about the lifestyle research of our older (institute) colleagues, we do not claim that we - as social scientists - are doing better research on the "everyday" of our present time. Maybe we have gained in precision by answering more detailed and more focused questions, or we might focus on better defined "pieces" of social life or culture, but this (questionable) precision does not come free. The cost is reduction and the eschewing of fundamental questions. The latter tend to be, unfortunately, holistic. Even if the answer given three or four decades ago looks naive or ideological (or both) today, it is worth looking back at research that was ambitious enough to ask such "heavy" questions.

\section{Acknowledgements:}

The research for this article was partly financed by the publication funds of the Centre for Social Sciences of the Hungarian Academy of Sciences and the support of projects No. K101046 and No. K115644 of the National Research, Development and Innovation Office in Hungary.

Study of the Polish lifestyle research has been supported by the project "Qualitative Data Archive at the Institute of Philosophy and Sociology, Polish Academy of Sciences" funded by the (Polish) Ministry of Science and Higher Education within the framework of the National Programme for the Development of Humanities - NPRH (grant No. 0027/NPRH2/ H11/81/2012).

Bibliography:

/// Andorka R. 1970. A társadalmi átrétegzódés és demográfiai hatásai II. Magyarországon, KSH Népességtudományi kutatóintézet.

/// Bertaux D., ed. 1981. Biography and Society: The Life History Approach in the Social Sciences, Sage.

/// Bourdieu P. 1984. Distinction: A Social Critique of the Judgement of Taste, Harvard University Press.

/// Bourdieu P. 1999. "The Specificity of the Scientific Field and the Social Conditions of the Progress of Reason," [in:] The Science Studies Reader, ed. M. Biagoli, Routledge, pp. 31-50. 
/// Dombos T., Pellandini-Simányi L. 2012. "Kids, Cars, or Cashews?," [in:] Communism Unwrapped: Consumption in Postwar Eastern Europe, eds. P. Bren, M. Neuburger, Oxford University Press, pp. 325-350.

/// Erdei F. 1933. "A makói tanyarendszer (I-III)" Népünk és Nyelvünk, vol. 4(6), pp. 81-91; vol. 7(10), pp. 140-148; vol. 11(12), pp. 193-198.

/// Gawin D., ed. 1999. Homo eligens. Spoteczeństwo świadomego wyboru, Wydawnictwo Instytutu Filozofii i Socjologii PAN.

/// Habermas J. 1981. Theory of Communicative Action, Beacon Press.

/// Hankiss E. 1977. Érték és társadalom, Magvető.

/// Heller Á. 1970. "The Marxist Theory of Revolution and the Revolution in Everyday Life,” Telos, vol. 33(6), pp. 212-223.

/// Heller M., Némedi D., Rényi Á. 1992. "A magyar nyilvánosság szerkezetváltozásai a Kádár-rendszerben," [in:] Értékrendek és társadalmi-kulturális változások, ed. P. Somlai, ELTE SZI, pp. 109-118.

/// Highmore B., ed. 2002. The Everyday Life Reader, Routledge.

/// Illyés Gy. 1936. Pusz̨ták népe, Nyugat.

/// Jahoda M., Lazarsfeld P.F., Zeisel H. 1933. Die Arbeitslosen von Marienthal: Ein soziographischer Versuch über die Wirkungen langandauernder Arbeitslosigkeit, Hirzel.

/// Kalekin-Fishman D. 2013. "Sociology of Everyday Life," Current Socio$\log y$, vol. 61(5-6), pp. 714-732.

/// Kemény I. 1992. “Az életforma fogalmához,” [in:] I. Kemény, Szociológiai Irások Szeged, Replika Könyvek, pp. 135-148.

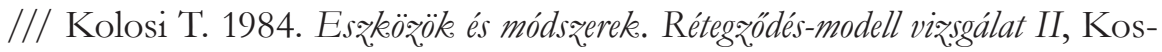
suth.

/// Konecki K.T., Kacperczyk A.M., Marciniak L.T. 2005. "Polish Qualitative Sociology: The General Features and Development," Forum Qualitative Sozialforschung / Forum: Qualitative Social Research, vol. 6(3), Art. 27, http:// nbn-resolving.de/urn:nbn:de:0114-fqs0503270, accessed 27.08.2014.

/// Kornai J. 1996. "Paying the Bill for Goulash Communism: Hungarian Development and Macro Stabilisation in a Political-Economy Perspective," Social Research, vol. 63(4), pp. 943-1040. 
/// Kovács I. 1937. A néma forradalom, Cserépfalvi.

/// Kovács J.M. 2009. "Taste of the Goulash: Understanding the Hungarian 'Variety of Capitalism,"” Tr@nsit online, http://www.iwm.at/read-listenwatch/transit-online/taste-of-the-goulash/, accessed 27.08.2014.

/// Krzemiński I. et al. 2005 [1983]. Polacy - jesień '80, Wydział Filozofii i Socjologii Uniwersytetu Warszawskiego.

/// Losonczi Á. 1977. Életmód az idóben, a tárgyakban és az értékekeben, Gondolat.

/// Losonczi Á. 1978. "Az életmódkutatás néhány elvi problémája," [in:] Életmódkutatás a szocialista országokbban, ed. M. Szántó, Kossuth, pp. 44-88.

/// Lüdtke A. 1995. History of Everyday Life: Reconstructing Historical Experiences and Ways of Life, Princeton University Press.

/// Majtényi Gy. 2014. "Texts, Structures and Experiences: The Society of State Socialist Hungary in Historical Perspective," Socio.bu. Special Visegrad Issue, doi: 10.18030/socio.hu.2014en.96.

/// Marody M., Kolbowski J. et al. 2004 [1981]. Polacy '80. Wi ize rzeczymistości dnia (nie)codziennego, Wydział Filozofii i Socjologii Uniwersytetu Warszawskiego.

/// Mátyus A. 1980. Holnapon innen, tegnapon túl, Szépirodalmi.

/// Nowak S. 1979. “System wartości społeczeństwa polskiego," Studia Socjologiczne, vol. 4, pp. 155-173. [English transl.: "Value Systems of Polish Society," Polish Sociological Bulletin, vol. 2, 1980, pp. 5-20].

/// Parsons T. 1937. The Structure of Social Action, McGraw Hill.

/// Sági M. n.d. Múvelódés és személyiség, Népművelési Propaganda Iroda.

/// Sas J.H. 1981. Nóies nooke, férfias férfiak, Akadémiai.

/// Savage M., Devine F., Cunningham N., Taylor M., Li Y., Hjellbrekke J. et al. 2014. "A New Model of Social Class? Findings from the BBC's Great British Class Survey Experiment," Sociology, vol. 48(6), pp. 437-444.

/// Siciński A., ed. 1976. Styl życia. Koncepcje i propozycje, Państwowe Wydawnictwo Naukowe.

/// Siciński A. 1978a. "Változások az életmódban," [in:] Életmódkutatás a szocialista országokban, ed. M. Szántó, Kossuth, pp. 135-144. 
/// Siciński A., ed. 1978b. Style życia. Prz̧emiany we wspótczesnej Polsce, Państwowe Wydawnictwo Naukowe.

/// Siciński A., ed. 1980. Problemy teoretyczne i metodologiczne badań stylu życia, Wydawnictwo Instytutu Filozofii i Socjologii PAN.

/// Siciński A. 1985. "Styl życia - kultura - wybór," Kultura i Społeczeństwo, vol. 29(2), pp. 47-53.

/// Siciński A. 1987. "Co nam się nie sprawdziło? Perspektywy przemian stylu życia w Polsce. Krytyka wcześniejszych założeń,” Odra, vol. 2, pp. $2-7$.

/// Siciński A., ed. 1988. Style ¿̇ycia w miastach polskich (u progu kryzysu), Zakład Narodowy im. Ossolińskich.

/// Siciński A., Wyka A. 1988. Badania rozumiejace stylu życia: narzedzia, Wydawnictwo Instytutu Filozofii i Socjologii PAN.

/// Straczuk J. 2015. "Andrzeja Sicińskiego badania stylów życia - spojrzenie z dystansu," Kultura i Społeczeństwo, vol. 59(3), pp. 125-145.

/// Sułek A., Nowak K., Wyka A., eds. 1989. Poza granicami socjologii ankietowej, Uniwersytet Warszawski.

/// Szabó Z. 1936. A tardi belyz̨et, Cserépfalvi.

/// Szabó Z. 1938. Cifra nyomorúság, Cserépfalvi.

/// Szalai S., ed. 1972. The Use of Time: Daily Activities of Urban and Suburban Populations in Twelve Countries, Mouton de Gruyter.

/// Szántó M. 1978. Életmódkutatás a squcialista országokeban, Kossuth.

/// Szelényi I., ed. 1973. Városszociológia, KJK.

/// Thomas W.I., Znaniecki F. 1918-1920. The Polish Peasant in Europe and America: Monograph of an Immigrant Group, University of Chicago Press.

/// Veres P. 1936. Az. Alföld parasðtsága, Oravetz István Könyvkiadóvállalat.

/// Widmar L. 1987. “Nekem Szalai az eszményképem volt...," Mozgó Világ, vol. 8, pp. 63-76.

/// Znaniecki F. 1922. Wstęp do Socjologï, Poznańskie Towarzystwo Przyjaciół Nauk.

/// Znaniecki F. 1927. The Object Matter of Sociology, University of Poznań. 


\section{/// Abstract}

In our article we will present two Eastern European examples of how sociological research on everyday life in the 1970s has been influenced by political and cultural circumstances and particular scientific traditions. From the early 1970s, sociology flourished in some countries of the Eastern Bloc, institutes were refounded, and research projects were heavily subsidised. Research into daily life - the so-called "socialist lifestyle" - was one of the main foci of sociological inquiry.

Recently, similar data collections from two such projects were discovered in the archives of academies of sciences in Hungary (HAS) and Poland (PAS). In both cases, we can see that the researchers stand decisively on the side of "high" culture, while taking a normative view of "low" cultural consumption. Even though there was no direct cooperation or interdependence between Hungarian and Polish "lifestyle" researchers, we can observe similar structures of thinking about socialist society. Western influence, mostly implicitly, is also visible.

Keywords:

culture versus structure, everyday life, history of Hungarian sociology, history of Polish sociology, holistic approach, interpretive analysis, lifestyle research, multi-method research, socialism

/// Piotr Filipkowski - sociologist, oral historian, researcher at the Institute of Philosophy and Sociology of the Polish Academy of Sciences (IFiS PAN), postdoctoral researcher at the Institute for Eastern European History, University of Vienna; coordinator and participant in various biographical-sociological and oral history documentation and research projects, co-founder of and collaborator on the Polish Oral History Archive, run by the History Meeting House in Warsaw, as well as the Qualitative Data Archive at his home institute; member of the Polish Oral History Association and the Polish Sociological Association. His Ph.D. (2008) was based on analysis of biographical narrative interviews with concentration camp survivors and published as Historia mówiona i wojna. Doświadczenie obozu koncentracyjnego w perspektywie narracji biograficznych [Oral History and War: Experience of a Concentration Camp from the Perspective of Biographical Narratives] (2010). He has published mainly on qualitative research methods and oral history theory and practice.

Email: pfilipkowski@ifispan.waw.pl 
/// Judit Gárdos - sociologist at the Centre for Social Sciences, Hungarian Academy of Sciences. She recently completed her dissertation on scientific practices of quantitative sociology. She also conducts critical analyses of archival practices. She has been involved in a number of Hungarian and EU-funded research projects. Recent publications: "History, Ontology, Science Studies: How to Study Open Science and Scientific Data," EASST Review (2016); "Archival Practices and the Making of 'Memories," New Review of Information Networking (2015) (with Natasha Mauthner); "Jak ułożyć puzzle? Badania nad kulturą węgierskich robotników z połowy lat siedemdziesiątych XX wieku i kilka zagadnień epistemologicznych,” Kultura $i$ spoteczeństwo (2015) [How to Solve the Puzzle? Research into the Culture of Hungarian Workers in the Mid-1970s and Several Epistemological Questions].

Email: gardos.judit@tk.mta.hu

/// Éva Kovács - professor, sociologist, research chair at the Centre for Social Sciences of the Hungarian Academy of Sciences and academic director at the Vienna Wiesenthal Institute for Holocaust Studies. She studied sociology and economics at the University of Economics in Budapest (Ph.D. 1994, habilitation 2009). Her research fields are the history of the Holocaust in Eastern Europe and the memory of socialism. She founded the audio-visual archive "Voices of the Twentieth Century." She has authored five monographs, edited eight volumes, and published numerous articles in peer-reviewed journals. Key publications: Mirror Splinters: On the Collective Memory of Socialism (in Hungarian) (2008); Early Confrontations of the Nazi Mass Murder of the Jews (2016) (with Regina Fritz and Béla Rásky); "Parallel Readings: Narratives of Violence," in Memory and Genocide: On What Remains and the Possibility of Representation, eds. Fazil Moradi et al. (2017).

Email:kovacs.eva@tk.mta.hu 
/// Vera Szabari - associate professor with tenure, Department of the History of Sociology, Eötvös Loránd University; HAS Centre for Social Sciences, Institute for Sociology. Main research fields: history of Hungarian sociology, science studies, social theories. Key publications: Opportunities of Hungarian Sociology between 1945 and 1948 (forthcoming); "Egy tanszék létrehozása az 1970-es évek Magyarországán Az," in Vita Publica: Tanulmányok Rényi Ágnes tisz̧teletére, eds. Vera Szabari, Erzsébet Takács, Eszter Pál (2015); ““1944’ a szociológiában. Akadémiai szociológia és antiszemitizmus Magyarországon," Socio.bu, 2015.

Email: szabari@tatk.elte.hu 